\title{
Challenges in Sociological Theory
}

\author{
William Outhwaite* \\ Newcastle University, Newcastle upon Tyne, UK \\ Keywords: social theory, grand theory, modernity, postcolonial theory, empiricism
}

The main challenge, I think, to sociological theory or to social theory more broadly remains that of bridging the gap between what Mills (1959), nearly 60 years ago, called "grand theory" and "abstracted empiricism." Over 200 years ago, Kant (1781) formulated a similar conception, that "thoughts without content are empty and perceptions without concepts are blind" (Gedanken ohne Inhalt sind leer, Anschauungen ohne Begriffe sind blind).

Sociology was transformed in the 1970s by a turn to social theory conceived not, or not mainly, in scientific terms but as a broader conceptual project with a long history. My colleague and friend Gillian Rose (1947-1995) opened her Masters course on sociological theory with Hobbes and Rousseau. Rather than seeing such thinkers as part of a pre-history of properly scientific sociology, on the other side of what Giddens (1972) criticized as a mythical "great divide," they could more usefully be seen as part of a continuous history of social and political theory.

Sociological theory, then, was transformed in what I would see as something like another " 30 glorious years" following on from the 30 -year post-war boom of western capitalism. In turn, it transformed the rest of sociology. Sociologists of deviance read and absorbed Foucault; sociologists of politics or sport read Gramsci, Althusser, or Norbert Elias. What Elias (1987) had himself criticized as the "withdrawal of sociologists into the present" since the end of the Second World War seemed possibly to be reversible.

This was also the time when the relation between philosophy and social theory was reconceived in terms of collaboration on an equal basis - for example, in Hans-Georg Gadamer's philosophical hermeneutics, in Habermas's image of philosophy's role as a "place-holder and interpreter" for the sciences (Habermas, 1981), or in Roy Bhaskar's revival of Locke's image of the philosopher as an "under-laborer," clearing the ground for scientific work (Bhaskar, 1975, p. 10).

Seen from the UK, all this appeared as sociology becoming more "continental" (always a slightly

Edited and Reviewed by: Maurizio Meloni,

University of Sheffield, UK

*Correspondence: William Outhwaite william.outhwaite@ncl.ac.uk

Specialty section: This article was submitted to Sociological Theory, a section of the journal

Frontiers in Sociology

Received: 05 April 2016 Accepted: 21 April 2016 Published: 03 May 2016

Citation: Outhwaite W (2016) Challenges in Sociological Theory. Front. Sociol. 1:5. doi: 10.3389/fsoc.2016.00005 suspect term) or, seen from North America, as more "European." The process was, however, a wider one; the reception of Gramsci or Althusser was actually slower in, say, West Germany, than in the English-speaking world, where New Left Review and its associated book series had an important role in making it available. Moving to the present, we might think of postcolonial theory, transcending the divide between literary and social theory as well as that between the activism of Frantz Fanon, Che Guevara, or Amílcar Cabral and later, more academic, theory.

This is, however, only one side of the story. In much of sociology, it often seems that the wave of theory has passed over, often leaving nothing but ritualistic footnotes attached to highly empiricist exercises in "normal science." There has been some attrition of theorists and of theory in university departments and a tendency either to ghettoize it or, alternatively, to water it down in more diffuse courses deemed more approachable for students with a limited attention span. I tend to describe the glass as half full, but it can with equal validity be called half-empty, as in Peter Wagner's more pessimistic assessment:

There was some revival of social theorising in the 1960s and 1970s ... again thriving on a positive intellectual and political climate just as ... in the late $1800 \mathrm{~s}$... But again, and to some extent analogous to what happened in the early 1900s, this positive conjuncture has vanished and the intellectual alliances have fallen apart again (Wagner, 2001, p. 24). 
On the other hand, as Turner (2009), p. 559, writes, focusing particularly on the US situation,

... social theory goes on, both within sociology and, increasingly, outside of it. The same forces that led to the estrangement between social theory and empirical sociology have brought social theory closer to political theory, to such topics as citizenship and such figures as Arendt and Schmitt, for example, and to other bodies of thought, such as pragmatism and cultural studies in the humanities.

The challenge, then, is for theory to demonstrate its relevance to historical and contemporary concerns. This is, in fact, easily done in a number of areas. One is theories of cosmopolitanism, bringing

\section{REFERENCES}

Bhaskar, R. (1975). A Realist Theory of Science. Leeds: Leeds Books. [New edition London: Verso, 2008].

Elias, N. (1987). The retreat of sociologists into the present. Theory Cult. Soc. 4, 323-347. doi:10.1177/026327687004002003

Giddens, A. (1972). Four myths in the history of social thought. Econ. Soc. 1, 357-385. doi:10.1080/03085147200000020

Habermas, J. (1981). Philosophy as Place-Holder and Interpreter. London: Heinemann. [Reprinted in Habermas, Philosophical-Political Profiles (1983)].

Kant, I. (1781). Critique of Pure Reason. Various editions.

Mills, C. W. (1959). The Sociological Imagination. New York: Oxford University Press. together questions of human rights and migration, transnational integration processes in Europe and elsewhere and, more broadly, the relation between the social and the political. Another, present since the beginnings of sociology though with false starts in nineteenth century evolutionary theory and twentieth century sociobiology, is the interface between the social and the (rest of the) natural world (physical, biological, neural, and so on) in what is increasingly being called the anthropocene age. I hope that this section will provide a useful site for work combining sociological theory with substantive analysis of issues of current concern.

\section{AUTHOR CONTRIBUTIONS}

The author confirms being the sole contributor of this work and approved it for publication.

Turner, S. P. (2009). "The future of social theory," in The New Blackwell Companion to Social Theory, ed. B.Turner (Oxford: Blackwell), 531-566.

Wagner, P. (2001). A History and Theory of the Social Sciences. London: SAGE.

Conflict of Interest Statement: The author declares that the research was conducted in the absence of any commercial or financial relationships that could be construed as a potential conflict of interest.

Copyright (c) 2016 Outhwaite. This is an open-access article distributed under the terms of the Creative Commons Attribution License (CC BY). The use, distribution or reproduction in other forums is permitted, provided the original author(s) or licensor are credited and that the original publication in this journal is cited, in accordance with accepted academic practice. No use, distribution or reproduction is permitted which does not comply with these terms. 